Article

\title{
First-Principles Investigations of the Structural, Anisotropic Mechanical, Thermodynamic and Electronic Properties of the $\mathrm{AlNi}_{2} \mathrm{Ti}$ Compound
}

\author{
Shuli Tang, Yefei Li *, Yimin Gao, Qiaoling Zheng, Zhiwei Liu and Xiangyi Ren \\ State Key Laboratory for Mechanical Behavior of Materials, Xi'an Jiaotong University, Xi'an 710049, China; \\ shulitangxjtu@126.com (S.T.); ymgao@mail.xjtu.edu.cn (Y.G.); qlzxjtu@163.com (Q.Z.); \\ yhcheng_36@163.com (Z.L.); mmerenxiangyi@126.com (X.R.) \\ * Correspondence: yefeili@126.com; Tel.: +86-29-8266-5479
}

Received: 26 December 2017; Accepted: 8 February 2018; Published: 11 February 2018

\begin{abstract}
In this paper, the electronic, mechanical and thermodynamic properties of $\mathrm{AlNi}_{2} \mathrm{Ti}$ are studied by first-principles calculations in order to reveal the influence of $\mathrm{AlNi}_{2} \mathrm{Ti}$ as an interfacial phase on ZTA (zirconia toughened alumina)/Fe. The results show that $\mathrm{AlNi}_{2} \mathrm{Ti}$ has relatively high mechanical properties, which will benefit the impact or wear resistance of the ZTA/Fe composite. The values of bulk, shear and Young's modulus are 164.2, 63.2 and 168.1 GPa respectively, and the hardness of $\mathrm{AlNi}_{2} \mathrm{Ti}(4.4 \mathrm{GPa})$ is comparable to common ferrous materials. The intrinsic ductile nature and strong metallic bonding character of $\mathrm{AlNi}_{2} \mathrm{Ti}$ are confirmed by $B / G$ and Poisson's ratio. $\mathrm{AlNi}_{2} \mathrm{Ti}$ shows isotropy bulk modulus and anisotropic elasticity in different crystallographic directions. At room temperature, the linear thermal expansion coefficient (LTEC) of $\mathrm{AlNi}_{2} \mathrm{Ti}$ estimated by quasi-harmonic approximation (QHA) based on Debye model is $10.6 \times 10^{-6} \mathrm{~K}^{-1}$, close to LTECs of zirconia toughened alumina and iron. Therefore, the thermal matching of ZTA/Fe composite

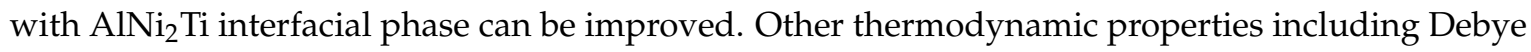
temperature, sound velocity, thermal conductivity and heat capacity, as well as electronic properties, are also calculated.
\end{abstract}

Keywords: first-principles calculation; mechanical modulus; anisotropy; thermal expansion coefficient; specific heat capacity

\section{Introduction}

$\mathrm{AlNi}_{2} \mathrm{Ti}$ is one of the Heusler compounds first identified by Heusler in 1903 [1]. The Heusler compounds are a group of ternary intermetallic alloys formed at the stoichiometric composition $\mathrm{X}_{2} \mathrm{YZ}$ (generally, $\mathrm{X}$ and $\mathrm{Y}$ are transition metals and $\mathrm{Z}$ is a b-subgroup element), with the doubly ordered $L 2_{1}$ structure based on the ordered B2 [2]. They have been widely reported to have excellent ferromagnetic, paramagnetic, mechanical and thermoelectric properties [3,4]. AlNi ${ }_{2} \mathrm{Ti}_{\text {with }} L 2_{1}$ structure can provide $\mathrm{NiAl}$ or Ni-base and Ti-base alloys with good high-temperature mechanical properties by precipitate strengthening [5-16]. Especially the mechanical properties of Fe-Ni-Al-Ti ferritic alloys, such as creep resistance and yield strength, can be significantly enhanced due to the $\mathrm{AlNi}_{2} \mathrm{Ti}$ precipitates [17-26]. In addition, $\mathrm{AlNi}_{2}$ Ti precipitate phase has also been observed in microstructures of Al-doped Ni-Ti shape memory alloys that have huge potential to be applied as functional material in many areas such as clinical medicine, biotechnology, automation, energy engineering, electronics industry, aeronautics and astronautics, owing to their pseudoelasticity, superplasticity and shape memory properties [27-32].

$\mathrm{AlNi}_{2} \mathrm{Ti}$ is also a common reaction product at the interface between phases. Recently, $\mathrm{AlNi}_{2} \mathrm{Ti}$ was observed at the interface in zirconia-toughened alumina (ZTA) or $\mathrm{Al}_{2} \mathrm{O}_{3}$ reinforced iron matrix composite with an $\mathrm{Ni}$-Ti transition layer that is expected to be applied for wear-resistant material $[33,34]$. 
The active elements $\mathrm{Ni}$ and $\mathrm{Ti}$ can promote the atom diffusion and chemical reaction between ZTA and Fe. Thus, $\mathrm{Al}_{2} \mathrm{O}_{3}$ will decompose and diffuse into the Ni-Ti layer, leading to the formation of interfacial phase $\mathrm{AlNi}_{2} \mathrm{Ti}$. The mechanical and thermal performance of $\mathrm{AlNi}_{2} \mathrm{Ti}$ is a key point for improving the interface properties and then wear resistance of composites, especially the thermal expansion coefficient (TEC) that influences the thermal matching of composite interfaces.

By now, a number of research works have been carried out on $\mathrm{AlNi}_{2} \mathrm{Ti}$ and other Heusler compounds by first-principles calculations. Wen et al. [35] reported the elastic constants and mechanical moduli under different pressures or temperatures of $\mathrm{Ni}_{2} \mathrm{XAl}(\mathrm{X}=\mathrm{Sc}, \mathrm{Ti}, \mathrm{V})$ compounds. The thermodynamic properties including heat capacity and thermal expansion coefficient as a function of temperature and pressure were demonstrated. They claimed that the influence of pressure on moduli and hardness decreases as the sequence of $\mathrm{Ni}_{2} \mathrm{ScAl}>\mathrm{Ni}_{2} \mathrm{TiAl}>\mathrm{Ni}_{2} \mathrm{VAl}$, while it has an opposite effect on ductility or anisotropy. Reddy and Kanchana [36] studied the effect of pressure and temperature on the Fermi surface and dynamic properties of a series of compounds $\mathrm{Ni}_{2} \mathrm{XAl}$ $(\mathrm{X}=\mathrm{Ti}, \mathrm{V}, \mathrm{Zr}, \mathrm{Nb}, \mathrm{Hf}$ and $\mathrm{Ta}$ ) using density functional theory (DFT). Their calculating results suggested that $\mathrm{AlNi}_{2} \mathrm{Ti}$ has lower specific heat and entropy but higher internal energy and free energy among the considered compounds [36]. The superconducting property of $\mathrm{Ni}_{2} \mathrm{NbAl}$ has also been studied and the critical superconducting transition temperature Tc calculated to be $3.1 \mathrm{~K}$ [36], which agrees well with the experimental result (Tc around 2.1 K) in previous work [37]. Compared with representative high-pressure superconductors, such as $\mathrm{H}_{3} \mathrm{~S}$ (Tc: $\left.178 \mathrm{~K}\right), \mathrm{PH}_{3}(T \mathrm{c}: 81 \mathrm{~K})$ [38] and $\mathrm{PtH}$ (Tc: $12.94 \sim 20.01 \mathrm{~K}$ ) [39], $\mathrm{Ni}_{2} \mathrm{NbAl}$ performs at a relatively low value of $T \mathrm{c}$. Sahariya and Ahuja [40] presented the energy bands and density of states of $\mathrm{AlNi}_{2} \mathrm{Ti}$ calculated using the DFT by linear combination of atomic orbitals (LCAO) approach. Zhou et al. [41] investigated the electronic and magnetic properties of $\mathrm{AlNi}_{2}$ Ti affected by swap defects and atomic antisite using first-principles calculations. The $\mathrm{Ni}_{\mathrm{Ti}(\mathrm{A})}$ antisite was found to be the most probable defect because of the lowest formation energy. Nevertheless, the properties of $\mathrm{AlNi}_{2} \mathrm{Ti}$ are still short of systematic theoretical study, especially the thermal properties and their anisotropies.

In this paper, a comprehensive and complementary study of the mechanical and thermal properties of $\mathrm{AlNi}_{2} \mathrm{Ti}$ crystal is conducted by first-principles calculation in order to provide significant theoretical directions for the fabrication and application of composites with interfacial phase $\mathrm{AlNi}_{2} \mathrm{Ti}$ and to offer a reference for the future research into $\mathrm{AlNi}_{2} \mathrm{Ti}$ or other Heusler alloys.

\section{Calculation Methods}

The $L 2_{1}$ cubic crystal structure with the $F m \overline{3} m$ space group of $\mathrm{AlNi}_{2} \mathrm{Ti}$ is shown in Figure 1 . The unit cell of $\mathrm{AlNi}_{2} \mathrm{Ti}$ has four formulas with a total of 16 atoms.

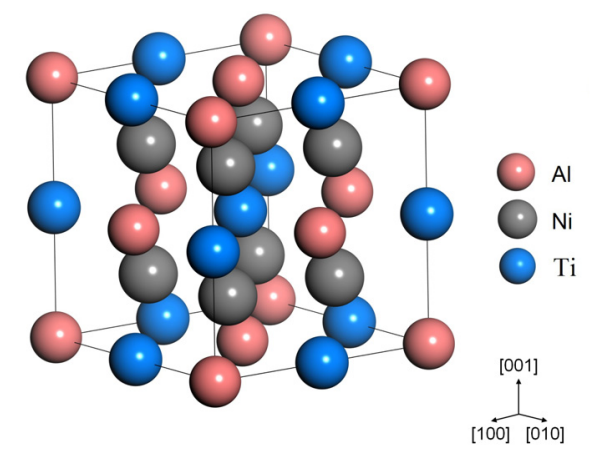

Figure 1. Crystal structure calculated for $\mathrm{AlNi}_{2} \mathrm{Ti}$ compounds.

The first-principles calculations based on DFT were implemented in Cambridge Serial Total Energy Package (CASTEP) code [42-44]. The ultra-soft pseudo potentials were employed to represent the interactions between ionic core and valence electrons. The valence electron configurations for 
$\mathrm{Al}, \mathrm{Ni}$ and Ti were $3 s^{2} 3 p^{1}, 3 d^{8} 4 s^{2}$ and $3 s^{2} 3 p^{6} 3 d^{2} 4 s^{2}$, respectively. A special $k$-point mesh was used for the numerical integrations in the entire Brillouin zone by setting as $8 \times 8 \times 8$ grid [45]. The Broyden-Fletcher-Goldfarb-Shannon (BFGS) minimization scheme was utilized for the optimization of lattice parameters and atomic positions in order to obtain the ground-state crystal structure. For the purpose of providing more abundant and reliable results, two approaches, i.e., the generalized gradient approximation (GGA) of Perdew Burke Ernzerhof (PBE) and Perdew Wang in 1991 (PW91) approaches, were adopted in exchange-correlation energy calculations [46]. It is capable of comparison with other DFT studies on $\mathrm{AlNi}_{2} \mathrm{Ti}$ by the same PBE-GGA approach [35,36] and local density approximation (LDA) approach $[7,35]$. A kinetic energy cut-off value of $500 \mathrm{eV}$ was used for plane wave expansions. The self-consistence convergence of the energy was set to $0.5 \times 10^{-6} \mathrm{eV} / \mathrm{atom}$. The quasi-harmonic approximation (QHA) Debye model was applied to predict the thermal properties of $\mathrm{AlNi}_{2} \mathrm{Ti}$ compounds.

\section{Results and Discussion}

\subsection{Crystal Parameters and Mechanical Properties}

The optimized ground-state structural parameters of $\mathrm{AlNi}_{2} \mathrm{Ti}$ compounds calculated by the GGA-PBE and GGA-PW91 approaches are shown in Table 1. It can be seen that the lattice parameters at $0 \mathrm{~K}$ in this study are close to other theoretical and experimental data $[22,35,36,47-54]$. The average deviation of results in this work to references for lattice parameters is less than $1 \%$. The chemical stability of the $\mathrm{AlNi}_{2} \mathrm{Ti}$ compound was evaluated by the cohesive energy $E_{\mathrm{coh}}$ and formation enthalpy $\Delta_{\mathrm{r}} \mathrm{H}$, which can be calculated using equations as follows [55].

$$
\begin{gathered}
E_{\mathrm{coh}}\left(\mathrm{AlNi}_{2} \mathrm{Ti}\right)=E_{\text {tot }}\left(\mathrm{AlNi}_{2} \mathrm{Ti}\right)-E_{\text {iso }}(\mathrm{Al})-2 E_{\text {iso }}(\mathrm{Ni})-E_{\text {iso }}(\mathrm{Ti}) \\
\Delta_{r} H\left(\mathrm{AlNi}_{2} \mathrm{Ti}\right)=E_{\mathrm{coh}}\left(\mathrm{AlNi}_{2} \mathrm{Ti}\right)-E_{\mathrm{coh}}(\mathrm{Al})-2 E_{\mathrm{coh}}(\mathrm{Ni})-E_{\mathrm{coh}}(\mathrm{Ti})
\end{gathered}
$$

where $E_{\text {tot }}$ represents the total energy of material and $E_{\text {iso }}$ represents the total energy of a single atom. From the calculated result in Table 1, the negative values of formation enthalpy and cohesive energy indicate the thermodynamic stability of $\mathrm{AlNi}_{2} \mathrm{Ti}$.

Table 1. The optimized ground-state structural parameters $\left(a, b, c\right.$, in $\AA ; V_{\text {cell }}$ in $\AA^{3} ; \rho$ in $\left.\mathrm{g} / \mathrm{cm}^{3}\right)$, atomic site, cohesive energy $\left(E_{c o h}, \mathrm{eV} /\right.$ f.u. $)$ and formation enthalpy $\left(\Delta_{r} H, \mathrm{eV} /\right.$ atom $)$ of $\mathrm{AlNi}_{2} \mathrm{Ti}$

\begin{tabular}{|c|c|c|c|c|c|c|c|c|}
\hline \multirow{2}{*}{ Method } & \multirow{2}{*}{$\begin{array}{c}\text { Lattice Parameters } \\
\qquad a=b=c\end{array}$} & \multirow{2}{*}{$V_{\text {cell }}$} & \multirow{2}{*}{$\rho$} & \multicolumn{3}{|c|}{ Atomic Site } & \multirow{2}{*}{$\Delta_{r} H$} & \multirow{2}{*}{$E_{c o h}$} \\
\hline & & & & Al & $\mathrm{Ni}$ & $\mathrm{Ti}$ & & \\
\hline GGA-PBE & $5.908\left(5.865^{\mathrm{a}}\right)$ & $206.242\left(201.75^{a}\right)$ & $\begin{array}{c}6.193 \\
\left(6.33^{a}\right)\end{array}$ & \multirow[t]{2}{*}{$4 \mathrm{a}(0,0,0)$} & \multirow[t]{2}{*}{$\begin{array}{c}8 c(0.25 \\
0.25,0.25)\end{array}$} & \multirow[t]{2}{*}{$\begin{array}{l}4 \mathrm{~b}(0.5 \\
0.5,0.5)\end{array}$} & -0.671 & -27.602 \\
\hline GGA-PW91 & 5.903 & 205.676 & 6.210 & & & & -0.643 & -33.173 \\
\hline $\begin{array}{c}\text { Other cal. } \\
\text { data }\end{array}$ & $5.906^{b}, 5.90^{c}, 5.828^{d}$ & & & & & & $\begin{array}{l}-0.658^{\mathrm{b}} \\
-0.662^{\mathrm{m}}\end{array}$ & \\
\hline Exp. data & $\begin{array}{c}5.906^{\mathrm{e}}, 5.883-5.910^{\mathrm{f}}{ }^{\prime} \\
5.819^{\mathrm{g}}, 5.876^{\mathrm{i}}, 5.942^{\mathrm{j}}, \\
5.889^{\mathrm{k}}, 5.865-5.886^{\mathrm{l}}{ }^{\prime}\end{array}$ & $203.61-206.40^{\mathrm{f}}$ & & & & & $\begin{array}{l}-0.747^{\mathrm{e}} \\
-0.578^{\mathrm{h}^{\prime}} \\
-0.579^{\mathrm{n}}\end{array}$ & \\
\hline EOS & 5.911 & 206.499 & 6.186 & & & & & \\
\hline
\end{tabular}
intermetallic compound.

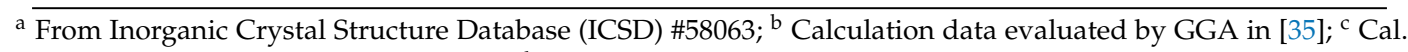
data evaluated by Reddy, et al. in [36]; ${ }^{\mathrm{d}}$ Cal. data evaluated by Monte Carlo simulations in [11]; ${ }^{\mathrm{e}}$ Exp. data in [47]; ${ }^{\mathrm{f}}$ Exp. data from [48]; ${ }^{\mathrm{g}}$ Data calculated from the selected area electron diffraction pattern in [22]; ${ }^{\mathrm{h}}$ Exp. data from [49]; ${ }^{\mathrm{i}}$ Data from handbook [50]; ${ }^{\mathrm{j}}$ Exp. data measured by X-ray diffraction in [51]; ${ }^{\mathrm{k}}$ Exp. data in [52]; ${ }^{\mathrm{l}}$ Exp. data in [53]; ${ }^{\mathrm{m}}$ Calculated values from a thermodynamic database in [54]; ${ }^{\mathrm{n}}$ Data measured by high-temperature reaction calorimeter in [54].

In order to study the mechanical properties of $\mathrm{AlNi}_{2} \mathrm{Ti}$ under external stress, the second-order elastic constants $c_{i j}$ are calculated by stress versus strain without stress controls. The stress-strain method is conducted using strain modes $[\varepsilon]^{T}=\eta\left[\begin{array}{llllll}1 & 0 & 0 & 1 & 0 & 0\end{array}\right]$, where $[\varepsilon]^{T}$ is the transpose of the strain 
matrix with Voigt notation and $\eta$ is the magnitude of strain [56]. The maximum strain amplitude is set as 0.003 and the number of steps for each strain is four. Then elastic constants $c_{i j}$ can be computed by Hooker's law, as presented in Table 2. Our results are similar to other calculation data $[18,35,36]$ and the values from the GGA-PW91 method are quite close to those from GGA-PBE. All elastic constants satisfy the Born-Huang stability criterion, so the $\mathrm{AlNi}_{2} \mathrm{Ti}$ compound has intrinsic stability [57]. The detailed criterion for cubic structure is that an elastically stable crystal should follow restrictions: $c_{44}>0$, $c_{11}>c_{12}$, and $c_{11}+2 c_{12}>0$ [58-60]. The value of $c_{11}$ is much larger than $c_{12}$ and $c_{44}$, indicating that it is stiff against uniaxial strain $\varepsilon_{1}$. Then the bulk modulus $(B)$ and shear modulus $(G)$ are computed by Voigt-Reuss-Hill approximation [61]. The Young's modulus E, Poisson's ratio $v$ and Vicker's hardness $H v$ are estimated by well-known relations $E=9 B G /(3 B+G), v=(3 B-2 G) /(6 B+2 G)[62-65]$ and $H v=2\left(k^{2} G\right)^{0.585}-3$, where $k=G / B$ [66]. The results show that the hardness of $\mathrm{AlNi}_{2} \mathrm{Ti}$ (4.4 GPa) is comparable to some common ferrous materials like pearlite steel (about $2 \mathrm{GPa}$ ), martensite steel (about $5.5 \mathrm{GPa}$ ) and white cast iron (about $6 \mathrm{GPa}$ ). Compared with Ni-Ti binary compounds, the hardness of $\mathrm{AlNi}_{2} \mathrm{Ti}$ is much higher than $\mathrm{NiTi}$ (2.7 or $1.1 \mathrm{GPa}$ with B2 or B19' structure respectively) and $\mathrm{NiTi}_{2}(1.6 \mathrm{GPa})$, and the mechanical moduli of $\mathrm{AlNi}_{2} \mathrm{Ti}$ are also higher than $\mathrm{NiTi}$ and $\mathrm{NiTi}_{2}$, but lower than $\mathrm{Ni}_{3} \mathrm{Ti}$ [55]. The Poisson's ratio of $\mathrm{AlNi}_{2} \mathrm{Ti}$ is determined as 0.32 . Since the Poisson's ratio is normally 0.25 for covalent materials and 0.3 for metallic materials, our result indicates that $\mathrm{AlNi}_{2} \mathrm{Ti}$ has a strong metallic bonding character. Besides, the value of $B / G$ is a criterion for justifying the ductility of the material; for tough materials, $B / G>1.75$, and for brittle materials, $B / G<1.75$. The $B / G$ value (2.6) indicates that $\mathrm{AlNi}_{2} \mathrm{Ti}$ has relatively higher toughness and ductility than common ceramics, such as $\mathrm{WC}\left(B / G=1.37\right.$ [67]), $\mathrm{SiO}_{2}(1.39[68]), \mathrm{TiC}(1.41[69,70]), \mathrm{Al}_{2} \mathrm{O}_{3}\left(1.52\right.$ [71]) and $\mathrm{ZrO}_{2}(2.3$ [71]). Therefore, the existence of $\mathrm{AlNi}_{2} \mathrm{Ti}$ at the $\mathrm{ZTA} / \mathrm{Fe}$ interface will benefit the mechanical properties of the composite with considerable certainty. Our results are close to other calculated data, except for hardness, which was estimated by another empirical equation in reference [35].

Table 2. Calculated independent elastic constants (GPa) compared to experimental and other theoretical values for the single crystalline $\mathrm{AlNi}_{2} \mathrm{Ti}$ intermetallic compound. Hereafter the mechanical modulus (GPa), Poisson's ratio, Vicker's hardness, shear anisotropic factors, and percent anisotropic index are also provided.

\begin{tabular}{|c|c|c|c|c|c|c|c|c|c|c|c|c|c|c|c|c|c|c|c|}
\hline \multirow[t]{2}{*}{ Method } & \multicolumn{3}{|c|}{ Elastic Constants } & \multicolumn{3}{|c|}{$B$} & \multicolumn{3}{|c|}{ G } & \multirow[t]{2}{*}{$B_{\mathrm{H}} / G_{\mathrm{H}}$} & \multirow[t]{2}{*}{$E$} & \multirow[t]{2}{*}{$v$} & \multirow[t]{2}{*}{$H_{V}$} & \multicolumn{3}{|c|}{$\begin{array}{c}\text { Shear } \\
\text { Anisotropic } \\
\text { Factors }\end{array}$} & \multicolumn{3}{|c|}{ Anisotropic Index } \\
\hline & $c_{11}$ & $c_{12}$ & $c_{44}$ & $B_{\mathrm{V}}$ & $B_{\mathrm{R}}$ & $B_{\mathrm{H}}$ & $G_{\mathrm{V}}$ & $G_{\mathrm{R}}$ & $\overline{G_{\mathrm{H}}}$ & & & & & $A_{1}$ & $A_{2}$ & $A_{3}$ & $A_{B}$ & $A_{G}$ & $A^{U}$ \\
\hline GGA-PBE & 208.1 & 142.2 & 97.6 & 164.2 & 164.2 & 164.2 & 71.8 & 54.7 & 63.2 & 2.6 & 168.1 & 0.32 & 4.4 & 2.96 & 2.96 & 2.96 & 0.00 & 0.14 & 1.56 \\
\hline GGA-PW91 & 209.3 & 143.4 & 94.8 & 165.4 & 165.4 & 165.4 & 70.1 & 54.2 & 62.1 & 2.7 & 165.6 & 0.33 & 4.1 & 2.88 & 2.88 & 2.88 & 0.00 & 0.13 & 1.47 \\
\hline Cal. data ${ }^{a}$ & $\begin{array}{c}215.8^{\mathrm{a}} \\
223^{\mathrm{b}}\end{array}$ & $\begin{array}{c}139.4^{\mathrm{a}} \\
135^{\mathrm{b}}\end{array}$ & $\begin{array}{l}98.7^{\mathrm{a}} \\
104^{\mathrm{b}^{\prime}}\end{array}$ & & $4.9^{\mathrm{a}}, 164$ & & & $5^{\mathrm{a}}, 74^{\mathrm{b}}$ & & $2.4^{\mathrm{a}}$ & $\begin{array}{c}178.1^{\mathrm{a}}, \\
193^{\mathrm{b}}\end{array}$ & & $8.1^{\mathrm{a}}$ & & $2.36^{b}$ & & & $0.104^{\mathrm{a}}$ & $1.165^{\mathrm{a}}$ \\
\hline Exp. data & $120^{c}$ & $97^{c}$ & $56^{c}$ & & & & & & & & & & & & & & & & \\
\hline EOS & & & & & 162.9 & & & & & & & & & & & & & & \\
\hline
\end{tabular}

The Helmholtz free energy is calculated by the following equation to investigate the stability of $\mathrm{AlNi}_{2} \mathrm{Ti}$ under elevated temperature [45]:

$$
E(V, T)=E_{\mathrm{gs}}(V)+E_{\mathrm{vib}}(V, T)+E_{\mathrm{ele}}(V, T),
$$

where $E_{\mathrm{gs}}$ refers to the ground state total energy; $E_{\mathrm{vib}}$ refers to vibrational free energy which can be given by QHA approximation based on the Debye model; $E_{\text {ele }}$ refers to the electron thermal excitations at finite temperature. Then the equilibrium volume and bulk modulus at the certain temperature can be obtained from isothermal curves $(E(V, T)-V)$ by fitting the Birch-Murnaghan equation of state as follows [72-74]:

$$
E(V)=\frac{B_{0} V_{0}}{B_{0}^{\prime}}\left[\frac{1}{B_{0}^{\prime}-1}\left(\frac{V}{V_{0}}\right)^{\left(1-B_{0}^{\prime}\right)}+\frac{V}{V_{0}}+\frac{B_{0}^{\prime}}{1-B_{0}^{\prime}}\right]+E_{0}
$$


Here $E(V)$ represents the Helmholtz free energy of crystal with a volume of $V ; E_{0}, B_{0}$ and $V_{0}$ are the energy, bulk modulus and cell volume, respectively, under $0 \mathrm{~K} ; B^{\prime}{ }_{0}$ refers to the first-order derivative of bulk modulus versus pressure under $0 \mathrm{~K}$. Then the computed lattice parameters and bulk moduli as the function of temperature are shown in Figure 2. It can be seen that with the rise of temperature from 0 to $1500 \mathrm{~K}$, the lattice parameter increases from 5.91 to $6.01 \AA$ while the bulk modulus declines from 162.95 to $138.05 \mathrm{GPa}$. The result indicates that $\mathrm{AlNi}_{2} \mathrm{Ti}$ is not particularly stable under elevated temperatures and there might be a certain amount of volume expansion when the temperature rises.

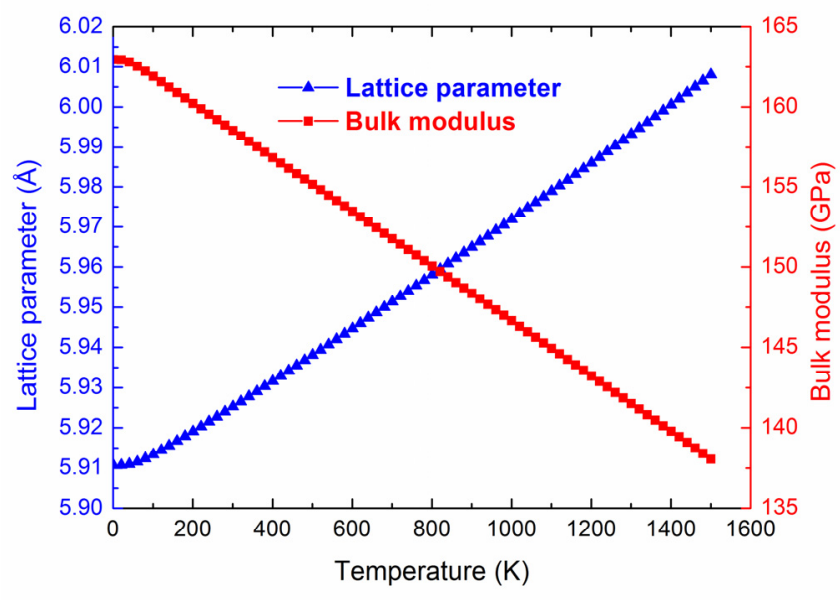

Figure 2. Temperature dependence of the lattice parameter and bulk modulus of $\mathrm{AlNi}_{2} \mathrm{Ti}$.

In addition, the compressibility calculated from the ratio of volume $(V)$ under a certain pressure to original volume $\left(V_{0}\right)$ without pressing is adopted to characterize the stability under high pressure and plasticity. Figure 3 shows the computed results of $\mathrm{AlNi}_{2} \mathrm{Ti}$ as well as some ceramic and metal materials for comparison. From Figure 3, under the same pressure, the volume change of $\mathrm{AlNi}_{2} \mathrm{Ti}$ is larger than $\mathrm{TiO}, \mathrm{TiO}_{2}, \mathrm{Fe}, \alpha-\mathrm{Al}_{2} \mathrm{O}_{3}$ and diamond, so the intermetallic compound $\mathrm{AlNi}_{2}$ Ti performs the best plasticity and deformation ability.

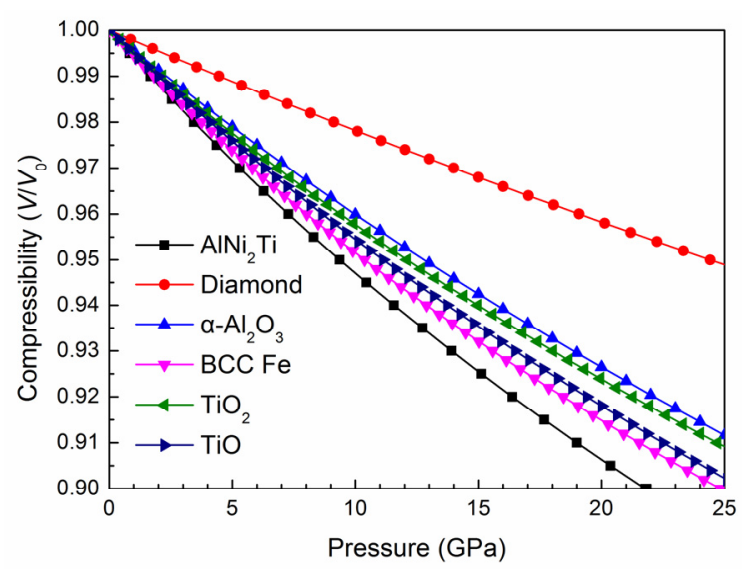

Figure 3. Compressibility characterized by normalized volume versus pressure of $\mathrm{AlNi}_{2} \mathrm{Ti}$, as well as diamond, $\alpha-\mathrm{Al}_{2} \mathrm{O}_{3}, \mathrm{BCC}$-iron, $\mathrm{TiO}_{2}$ and $\mathrm{TiO}$ for comparison. 


\subsection{Anisotropy of Mechanical Moduli}

The elastic anisotropy of $\mathrm{AlNi}_{2} \mathrm{Ti}$ with cubic structure is investigated by computing the values of bulk and Young's moduli under different directions, as in the following equations [75]:

$$
\begin{gathered}
B=1 /\left(s_{11}+2 s_{12}\right), \\
E=1 /\left[s_{11}-2\left(s_{11}-s_{12}-\frac{1}{2} s_{44}\right)\left(l_{1}^{2} l_{2}^{2}+l_{2}^{2} l_{3}^{2}+l_{3}^{2} l_{1}^{2}\right)\right],
\end{gathered}
$$

Here $s_{i j}$ represents the elastic compliance matrix, which is the inverse matrix of $c_{i j} . l_{1}, l_{2}$ and $l_{3}$ are the directional cosines. In spherical coordinates, $l_{1}, l_{2}$ and $l_{3}$ are computed by $l_{1}=\sin \theta \cos \varphi$, $l_{2}=\sin \theta \sin \varphi$, and $l_{3}=\cos \theta$ respectively. Then the obtained three-dimensional contour plots of elastic moduli are shown in Figure 4, revealing that the bulk modulus of $\mathrm{AlNi}_{2} \mathrm{Ti}$ shows spherical morphology while the Young's modulus shows relatively stronger anisotropy. From the planar projections of bulk and Young's moduli on [001] and [110] crystallographic planes in Figure 4, the anisotropy of the Young's modulus on both [001] and [110] planes is apparent. The bulk and Young's moduli on principal crystallographic directions can be calculated by

$$
\begin{gathered}
B_{[100]}=1 /\left(s_{11}+s_{12}+s_{13}\right), B_{[010]}=1 /\left(s_{12}+s_{22}+s_{23}\right), B_{[001]}=1 /\left(s_{13}+s_{23}+s_{33}\right), \\
E_{[100]}=1 / s_{11}, E_{[010]}=1 / s_{22}, E_{[001]}=1 / s_{33},
\end{gathered}
$$
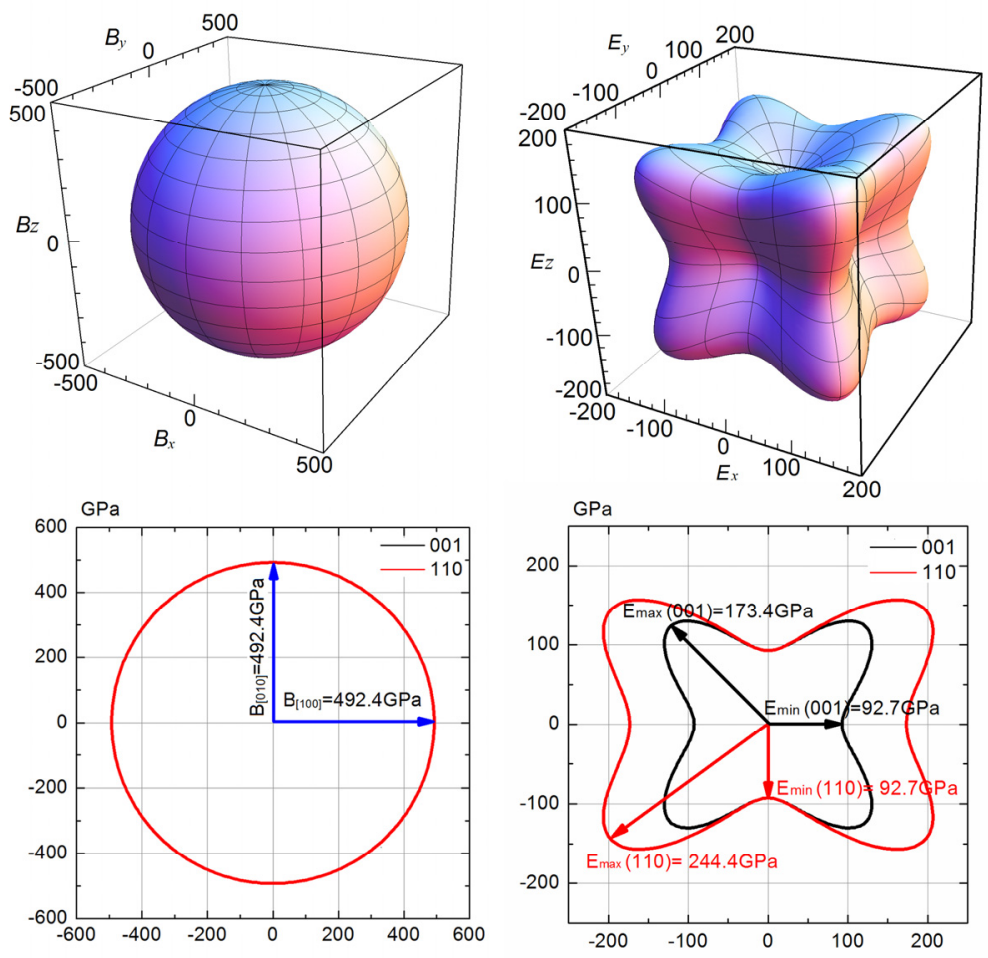

Figure 4. The surface constructions of the bulk modulus $B$ and Young's modulus $E$ of $\mathrm{AlNi}_{2} \mathrm{Ti}$; the corresponding planar projections of $B$ on the [001] crystallographic plane and planar projections of $E$ on [001] and [110] crystallographic planes are shown below.

The results indicate that the bulk modulus of AlNi2Ti is $B_{[100]}=B_{[010]}=492.4 \mathrm{GPa}$, which shows obvious isotropy. As for the Young's modulus, the maximum and minimum values on the [001] plane are $E_{[110]}=173.4 \mathrm{GPa}$ and $E_{[100]}=92.7 \mathrm{GPa}$; the maximum and minimum values on the [110] plane are $E_{[111]}=244.4 \mathrm{GPa}$ and $E_{[001]}=92.7 \mathrm{GPa}$, respectively . 
Three shear anisotropic factors $\left(A_{1}, A_{2}\right.$ and $\left.A_{3}\right)$ for cubic crystal are calculated to characterize the elastic anisotropy, which were defined by Ravindran et al. as $A_{1}=A_{2}=A_{3}=2 c_{44} /\left(c_{11}-c_{12}\right)$ [76] . As in Table 2, the computed values of $A_{1}, A_{2}$ and $A_{3}$ were 2.96 by the GGA-PBE method and 2.88 by the GGA-PW91 method, demonstrating that the shear modulus of $\mathrm{AlNi}_{2} \mathrm{Ti}$ has a strong directional dependence, because the values of $A_{1}, A_{2}$ and $A_{3}$ should be one for an isotropic crystal [77]. Besides, Ranganathan and Ostoja-Starzewski proposed another universal anisotropy index $A^{U}$ determined by [78]:

$$
A^{U}=5\left(G_{V} / G_{R}\right)+\left(B_{V} / B_{R}\right)-6,
$$

The elastic anisotropy can also be evaluated by the percent anisotropies $A_{B}$ and $A_{G}$ in compression and shear modes as follows [79]:

$$
\begin{aligned}
& A_{B}=\left(B_{V}-B_{R}\right) /\left(B_{V}+B_{R}\right), \\
& A_{G}=\left(G_{V}-G_{R}\right) /\left(G_{V}+G_{R}\right),
\end{aligned}
$$

The results in Table 2 show that our results are close to the data calculated by others. The value of $A^{U}$ over zero implies that $\mathrm{AlNi}_{2} \mathrm{Ti}$ shows the universal anisotropy of mechanical moduli; $A_{B}$ has zero value while the value of $A_{G}$ is slightly larger than zero, so $\mathrm{AlNi}_{2} \mathrm{Ti}$ has isotropic bulk modulus and anisotropic shear modulus [77], which agrees well with the results from the Voigt and Reuss approximations.

\subsection{Sound Velocities and Thermal Conductivity}

The sound velocity in a crystal is an important parameter for thermodynamic properties. For cubic structure, the sound velocities of both longitudinal and transverse waves on principal crystallographic directions should be evaluated by the procedure of Braggar using elastic constants, as in the relations below [80-83]:

$$
\begin{gathered}
\text { for }[100] v_{l}=\sqrt{c_{11} / \rho},[010] v_{t 1}=[001] v_{t 2}=\sqrt{c_{44} / \rho}, \\
\text { for }[110] v_{l}=\sqrt{\left(c_{11}+c_{12}+2 c_{44}\right) / 2 \rho},[1 \overline{1} 0] v_{t 1}=\sqrt{\left(c_{11}-c_{12}\right) / \rho},[001] v_{t 2}=\sqrt{c_{44} / \rho}, \\
\text { for }[111] v_{l}=\sqrt{\left(c_{11}+2 c_{12}+4 c_{44}\right) / 3 \rho},[11 \overline{2}] v_{t 1}=v_{t 2}=\sqrt{\left(c_{11}-c_{12}+c_{44}\right) / 3 \rho},
\end{gathered}
$$

Here $\rho$ is the theoretical density of the compound; $v_{l}$ is the longitudinal sound velocity; $v_{t 1}$ and $v_{t 2}$ are the first and the second transverse mode, respectively. Obviously, $c_{11}$ determines the longitudinal sound velocity along [100] direction, while $c_{44}$ corresponds to the transverse modes. The sound velocities in the [110] and [111] directions are related to all values of $c_{11}, c_{12}$ and $c_{44}$. The anisotropy of sound velocities implies the elastic anisotropy of crystal. The calculated results are tabulated in Table 3.

\begin{tabular}{|c|c|c|c|c|c|c|c|c|c|c|c|c|c|c|c|c|c|c|}
\hline \multirow{2}{*}{ Species } & \multicolumn{3}{|c|}{ [100] } & \multicolumn{3}{|c|}{ [010] } & \multicolumn{3}{|c|}{ [001] } & \multicolumn{3}{|c|}{ [110] } & \multicolumn{3}{|c|}{ [111] } & \multirow[b]{2}{*}{$v_{1}$} & \multirow[b]{2}{*}{$v_{\mathrm{t}}$} & \multirow[b]{2}{*}{$v_{\mathrm{m}}$} \\
\hline & $v_{l}$ & $v_{t 1}$ & $v_{t 2}$ & $v_{l}$ & $v_{t 1}$ & $v_{t 2}$ & $v_{l}$ & $v_{t 1}$ & $v_{t 2}$ & $v_{l}$ & $v_{t 1}$ & $v_{t 2}$ & $v_{l}$ & $v_{t 1}$ & $v_{t 2}$ & & & \\
\hline $\mathrm{AlNi}_{2} \mathrm{Ti}$ & 5797 & 3971 & 3971 & 5797 & 3971 & 3971 & 5797 & 3971 & 3971 & 6637 & 3262 & 3971 & 6894 & 2967 & 2967 & 6334 & 3195 & 3583 \\
\hline $\mathrm{Ni}_{3} \mathrm{Ti}$ & 6565 & 3277 & 3625 & 6565 & 3277 & 3625 & 6565 & 3277 & 3277 & 6565 & 3277 & 3625 & 7243 & 1172 & 3513 & 6427 & 3550 & 3955 \\
\hline
\end{tabular}
For comparison, the sound velocities of the $\mathrm{Ni}_{3} \mathrm{Ti}$ intermetallic compound with a hexagonal structure are also calculated. It is indicated that the longitudinal sound velocities along all directions of $\mathrm{Ni}_{3} \mathrm{Ti}$ are higher than $\mathrm{AlNi}_{2} \mathrm{Ti}$.

Table 3. Calculated anisotropic sound velocities of $\mathrm{AlNi}_{2} \mathrm{Ti}$ intermetallic compounds, together with the values of $\mathrm{Ni}_{3} \mathrm{Ti}$. The unit of velocity is $\mathrm{m} / \mathrm{s}$. 
Besides, the total transverse, longitudinal and mean sound velocities $\left(v_{t}, v_{l}\right.$ and $\left.v_{m}\right)$ can be calculated from density $\rho$, bulk and shear moduli $(B$ and $G)$, as following equations $[84,85]$.

$$
\begin{gathered}
v_{t}=\sqrt{\frac{G}{\rho}} \\
v_{l}=\sqrt{\frac{\left(B+\frac{4}{3} G\right)}{\rho}} \\
v_{m}=\left[\frac{1}{3}\left(\frac{2}{v_{t}^{3}}+\frac{1}{v_{l}^{3}}\right)\right]^{-1 / 3},
\end{gathered}
$$

In Table 3, the velocities of $\mathrm{AlNi}_{2} \mathrm{Ti}$ are slightly lower than $\mathrm{Ni}_{3} \mathrm{Ti}$. Once the mean sound velocities are obtained, the Debye temperature $\left(\Theta_{D}\right)$ can be estimated by [86]:

$$
\Theta_{D}=\frac{h}{k_{B}}\left[\frac{3 n}{4 \pi}\left(\frac{N_{A} \rho}{M}\right)\right]^{1 / 3} v_{m},
$$

where $h$ is the Planck's constant; $k_{B}$ is the Boltzmann constant; $N_{A}$ is the Avagadro's constant; $n$ is the number of atoms per formula; and $M$ is the molecular weight. The calculated Debye temperature values of $\mathrm{AlNi}_{2} \mathrm{Ti}$ and $\mathrm{Ni}_{3} \mathrm{Ti}$ are shown in Table 4. Our results are in good agreement with both the theoretical values and experimental data $[35,87]$. The Debye temperature of $\mathrm{Ni}_{3} \mathrm{Ti}$ is higher than that of $\mathrm{AlNi}_{2} \mathrm{Ti}$, so the inter-atomic force in $\mathrm{Ni}_{3} \mathrm{Ti}$ is correspondingly stronger than $\mathrm{AlNi}_{2} \mathrm{Ti}$. This may be

\begin{tabular}{|c|c|c|c|c|c|c|c|c|c|c|c|}
\hline Species & Model & $\Theta_{D}$ & $\begin{array}{c}\bar{M} \\
\left(10^{-26}\right)\end{array}$ & $\begin{array}{c}P \\
\left(10^{28}\right)\end{array}$ & $\begin{array}{l}{[100]} \\
k_{\min }\end{array}$ & $\begin{array}{l}{[010]} \\
k_{\min }\end{array}$ & $\begin{array}{l}{[001]} \\
k_{\min }\end{array}$ & $\begin{array}{l}{[110]} \\
k_{\min }\end{array}$ & $\begin{array}{l}{[111]} \\
k_{\min }\end{array}$ & $k_{\min }$ & $\begin{array}{c}k \\
\text { (Exp.) }\end{array}$ \\
\hline \multirow{2}{*}{$\mathrm{AlNi}_{2} \mathrm{Ti}$} & Clark & \multirow{2}{*}{$455.1\left(462^{\mathrm{a}}, 411^{\mathrm{b}}\right)$} & \multirow[t]{2}{*}{7.97} & & 0.85 & 0.85 & 0.85 & 1.16 & 1.37 & 1.14 & \multirow{2}{*}{$21.4^{\mathrm{c}}$} \\
\hline & Cahill & & & 7.76 & 1.39 & 1.39 & 1.39 & 1.40 & 1.30 & 1.29 & \\
\hline \multirow{2}{*}{$\mathrm{Ni}_{3} \mathrm{Ti}$} & Clark & \multirow{2}{*}{516.6} & \multirow[t]{2}{*}{9.29} & & 1.36 & 1.36 & 1.45 & 1.36 & 1.26 & 1.31 & \\
\hline & Cahill & & & 8.43 & 1.44 & 1.44 & 1.40 & 1.44 & 1.28 & 1.45 & \\
\hline
\end{tabular}
the reason why the moduli of $\mathrm{Ni}_{3} \mathrm{Ti}$ are relatively larger than $\mathrm{AlNi}_{2} \mathrm{Ti}$.

Table 4. Calculated thermodynamic parameters: Debye temperatures (K), and minimum thermal conductivities $(k, \mathrm{~W} /(\mathrm{m} \cdot \mathrm{K}))$ of the $\mathrm{AlNi}_{2} \mathrm{Ti}$ intermetallic compound and $\mathrm{Ni}_{3} \mathrm{Ti}$ for comparison.

Thermal conductivity characterizes the thermal transportation behavior of material. In this study, the minimum thermal conductivity $\left(k_{\min }\right)$ of $\mathrm{AlNi}_{2} \mathrm{Ti}$ as well as $\mathrm{Ni}_{3} \mathrm{Ti}$ for comparison is estimated by Clarke's model and Cahill's model as follows [88,89]:

in Clark's model,

$$
k_{\min }=0.87 k_{B} \bar{M}^{-2 / 3} E^{1 / 2} \rho^{1 / 6},
$$

in Cahill's model,

$$
k_{\min }=\frac{k}{2.48} P^{2 / 3}\left(v_{l}+2 v_{t}\right),
$$

where $k_{\mathrm{B}}$ is the Boltzmann constant; $\bar{M}=M /\left(m \cdot N_{A}\right)$ represents the average mass per atom; $E$ is the Young's modulus; $\rho$ is the density; $P$ is the density of number of atoms per volume; and $v_{l}$ and $v_{t}$ refer to the longitudinal and transverse sound velocities, respectively. The results in Table 4 show that the minimum thermal conductivities of $\mathrm{AlNi}_{2} \mathrm{Ti}$ predicted by Clark's model $\left(1.14 \mathrm{~W} \cdot \mathrm{m}^{-1} \mathrm{~K}^{-1}\right)$ are slightly smaller than Cahill's model $\left(1.29 \mathrm{~W} \cdot \mathrm{m}^{-1} \mathrm{~K}^{-1}\right)$. The minimum thermal conductivities of $\mathrm{AlNi}_{2} \mathrm{Ti}$ by both models are close to that of $\mathrm{Ni}_{3} \mathrm{Ti}$, while the values of $\mathrm{AlNi}_{2} \mathrm{Ti}$ are relatively smaller, probably due to the higher modulus of $\mathrm{Ni}_{3} \mathrm{Ti}$. The calculated thermal conductivities are smaller than the experimental value [2], because the experimental measurement is conducted using $\mathrm{AlNi}_{2} \mathrm{Ti}_{\text {alloy }}$ 
rather than single phase. Besides, the anisotropy of minimum thermal conductivity estimated by Clark's model is consistent with that by Cahill's model to some degree. The $k_{\min }$ has the same value in the [100], [010] and [001] directions by both models. However, the largest $k_{\min }$ estimated within Clark's model is $1.37 \mathrm{~W} \cdot \mathrm{m}^{-1} \mathrm{~K}^{-1}$ in [111] direction; as for Cahill's model, the largest $k_{\min }\left(1.40 \mathrm{~W} \cdot \mathrm{m}^{-1} \mathrm{~K}^{-1}\right)$ is in [110] direction.

\subsection{Thermal Expansion Coefficient and Heat Capacity}

The Helmholtz free energy $E(V, T)-V$ curves under different temperatures are obtained and presented in Figure 5. Then the equilibrium volumes at each temperature can be computed by fitting the Birch-Murnaghan equation of state. The volume expansions $\left(V / V_{0}\right)$ under various temperatures are shown in Figure 6. It can be seen that the volume expansion of $\mathrm{AlNi}_{2} \mathrm{Ti}$ increases with temperature and is greater than that of Ni-Ti binary compounds, which were investigated in reference [55].

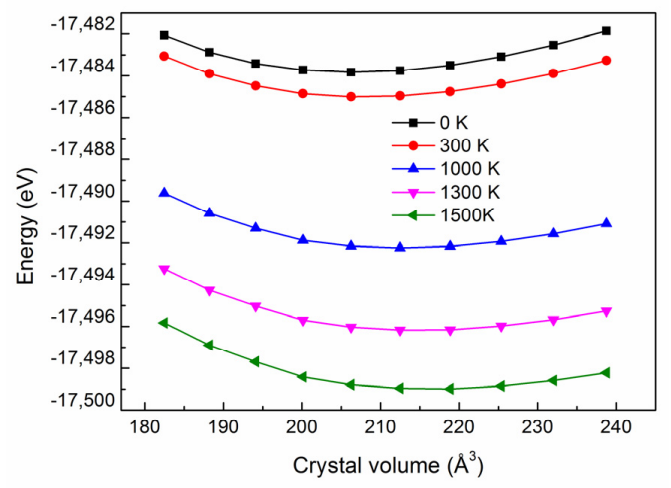

Figure 5. Dependence of the Helmholtz free energy $E(V, T)$ on the crystal volume of $\mathrm{AlNi}_{2} \mathrm{Ti}_{\mathrm{under}}$ different temperatures.

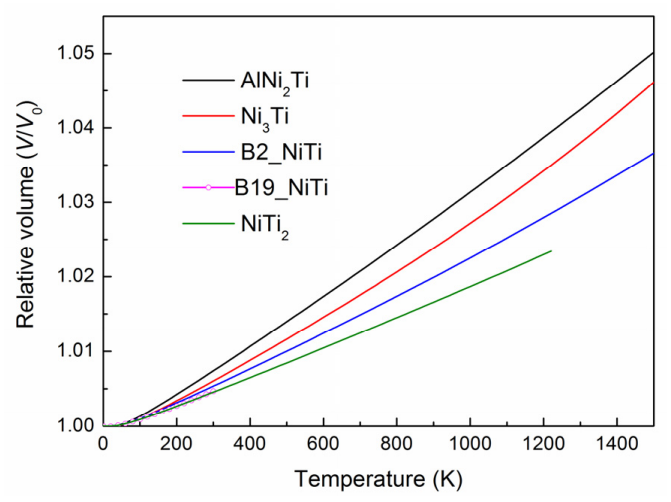

Figure 6. Volume expansions evaluated by $V / V_{0}$ as a function of temperature, where $V_{0}$ refers to the equilibrium volume at $0 \mathrm{~K}$.

Then the volumetric TEC $\lambda$ can be calculated by $\lambda=(\partial V / \partial T) / V$. Moreover, the linear TEC $\alpha$ of cubic $\mathrm{AlNi}_{2} \mathrm{Ti}$ determined as $\alpha=\lambda / 3$ is near the LTEC of $\mathrm{Ni}_{3} \mathrm{Ti}$, and higher than other Ni-Ti binary compounds, as shown in Figure 7. With the temperature rising, the LTEC of $\mathrm{AlNi}_{2} \mathrm{Ti}_{\text {increases }}$ rapidly first and then shows nearly linear growth with relatively slow increments above $200 \mathrm{~K}$. At room temperature ( $300 \mathrm{~K}$ approximately), the LTECs of $\mathrm{AlNi}_{2} \mathrm{Ti}$ and $\mathrm{Ni}$-Ti binary compounds are AlNi 2 Ti: $10.6 \times 10^{-6} \mathrm{~K}^{-1}, \mathrm{Ni}_{3}$ Ti: $8.92 \times 10^{-6} \mathrm{~K}^{-1}$, B2_NiTi: $7.50 \times 10^{-6} \mathrm{~K}^{-1}, \mathrm{NiTi}_{2}: 6.31 \times 10^{-6} \mathrm{~K}^{-1}$, respectively, so $\mathrm{AlNi}_{2} \mathrm{Ti}$ has the largest LTEC. However, the LTEC of $\mathrm{Ni}_{3} \mathrm{Ti}$ increases faster and exceeds the LTEC of $\mathrm{AlNi}_{2} \mathrm{Ti}$ under elevated temperatures above $1200 \mathrm{~K}$. Since $\mathrm{AlNi}_{2} \mathrm{Ti}$ is considered one of the interfacial phases in ZTA-reinforced iron matrix composite, the thermal matching property of the 
$\mathrm{ZTA} / \mathrm{Fe}$ interface should be improved as much as possible. In this study, the LTEC of $\mathrm{AlNi}_{2} \mathrm{Ti}_{\text {is }}$ quite near to ZTA (7.0-9.5 $\times 10^{-6} \mathrm{~K}^{-1}$ [90]) and Fe $\left(9.2-16.9 \times 10^{-6} \mathrm{~K}^{-1}\right.$ [91]), so the ZTA/Fe composite with $\mathrm{AlNi}_{2} \mathrm{Ti}$ at the interface will have excellent thermal shock resistance.

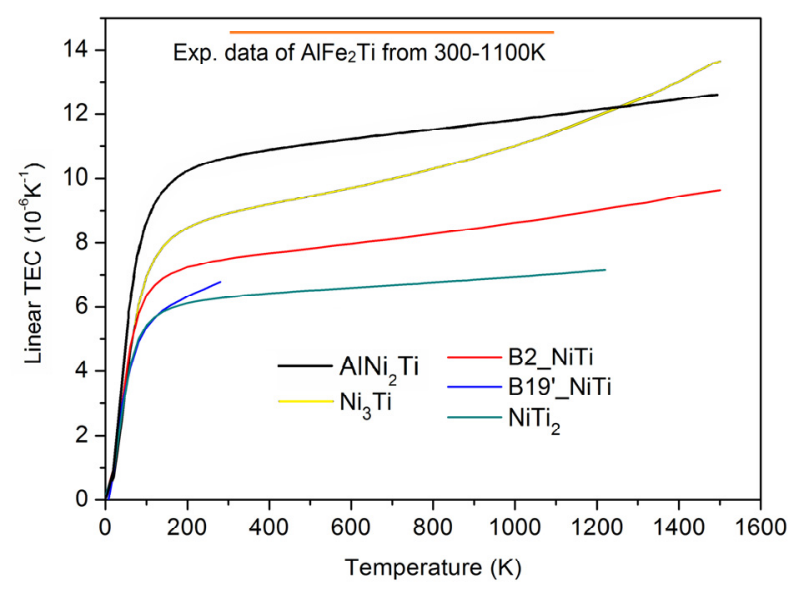

Figure 7. Linear thermal expansion coefficients of $\mathrm{AlNi}_{2} \mathrm{Ti}$ and $\mathrm{Ni}$-Ti binary compounds as a function of temperature [52].

Figure 7 also shows the LTEC of another Heusler compound $\mathrm{AlFe}_{2} \mathrm{Ti}\left(14.5 \times 10^{-6} \mathrm{~K}^{-1}\right.$ [52]), which is higher than our result. In addition, the specific heats at constant pressure $\left(C_{p}\right)$ and constant volume $\left(C_{v}\right)$ are studied and their values follow the equation

$$
C_{p}-C_{v}=\lambda^{2} V(T) T B
$$

where $\lambda$ is the volumetric thermal expansion coefficient; $V(T)$ and $B$ are the cell volume and crystal bulk modulus at temperature $T$. The calculated results for specific heats are shown in Figure 8, indicating that our results agree well with the measured $C_{p}$ of $\mathrm{AlNi}_{2} \mathrm{Ti}$ in experiment from 102 to $606.1 \mathrm{~K}$ [92]. At low temperature, $C_{p}$ and $C_{v}$ both increase rapidly with the temperature rising and the increment speed decreases substantially at higher temperatures. The high temperature limit of $C_{v}$ tends to approaching the classic Dulong-Petit limit, and $C_{p}$ keeps growing due to the work done by the volumetric expansion.

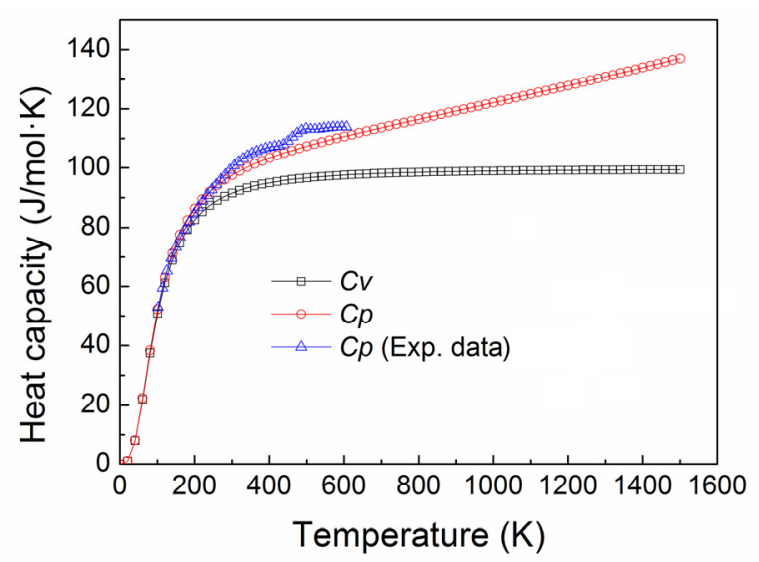

Figure 8. The specific heats at constant pressure $\left(C_{p}\right)$ or volume $\left(C_{p}\right)$ of $\mathrm{AlNi}_{2} \mathrm{Ti}$ as a function of temperature [92]. 
In order to explore the low-temperature heat capacity of $\mathrm{AlNi}_{2} \mathrm{Ti}$ with metallic features, $C_{p}$ can be estimated from the calculations of the electronic structures and elastic constants, which is given by [67].

$$
\begin{gathered}
C_{p}(T)=\gamma T+\beta T^{3}, \\
\gamma=\frac{1}{3} \pi^{2} k_{\mathrm{B}}^{2} D_{\mathrm{f}}, \\
\beta=\frac{12 \pi^{4} R n}{5 \Theta_{D}^{3}},
\end{gathered}
$$

where $\gamma$ and $\beta$ are the coefficients of electronic and lattice heat, respectively; $D_{\mathrm{f}}$ is the density of state (DOS) value at the Fermi level; $R$ is the molar gas constant and $n$ is the total number of atoms per formula unit. It is worth mentioning that $\Theta_{D}$ can only describe the temperature-dependence of $C_{p}$ when the temperature is lower than $\Theta_{D} / 10$ [93]. Therefore, the values of $D_{\mathrm{f}}, \gamma$ and $\beta$ are shown in Table 5 and the $C_{p}-T$ curve of $\mathrm{AlNi}_{2} \mathrm{Ti}$ and Ni-Ti binary compounds for comparison from 0 to $45 \mathrm{~K}$ is obtained in Figure 9.

Table 5. Theoretically calculated low-temperature specific heat of $\mathrm{AlNi}_{2} \mathrm{Ti}$ and $\mathrm{Ni}$-Ti binary compounds, including the total density of states at the Fermi level $\left(D_{\mathrm{f}}\right.$, states $\left./(\mathrm{eV} \cdot \mathrm{atom})\right)$, the characteristic parameters of electron $\left(\gamma, \mathrm{mJ} /\left(\mathrm{K}^{2} \cdot \mathrm{mol}\right)\right)$ and phonon $\left(\beta, \mathrm{mJ} /\left(\mathrm{K}^{4} \cdot \mathrm{mol}\right)\right)$ specific heat, and the specific heat $\left(C_{p}, \mathrm{~J} /(\mathrm{K} \cdot \mathrm{mol})\right)$ at $3 \mathrm{~K}$ and $30 \mathrm{~K}$ for comparison.

\begin{tabular}{cccccc}
\hline Species & $D_{\mathrm{f}}$ & $\gamma$ & $\beta$ & $C_{p}$ (3 K) & $C_{p}$ (30 K) \\
\hline $\mathrm{AlNi}_{2} \mathrm{Ti}$ & 0.416 & 0.981 & 0.0825 & 0.00517 & 2.26 \\
$\mathrm{Ni}_{3} \mathrm{Ti}$ & 0.113 & 0.267 & 0.0569 & 0.00234 & 1.54 \\
$\mathrm{~B} 2 \_\mathrm{NiTi}$ & 0.714 & 1.68 & 0.0577 & 0.00661 & 1.61 \\
$\mathrm{~B} 19^{\prime} \_\mathrm{NiTi}$ & 0.406 & 0.957 & 0.0806 & 0.00505 & 2.21 \\
$\mathrm{NiTi}_{2}$ & 0.763 & 1.80 & 0.115 & 0.00850 & 3.16 \\
\hline
\end{tabular}

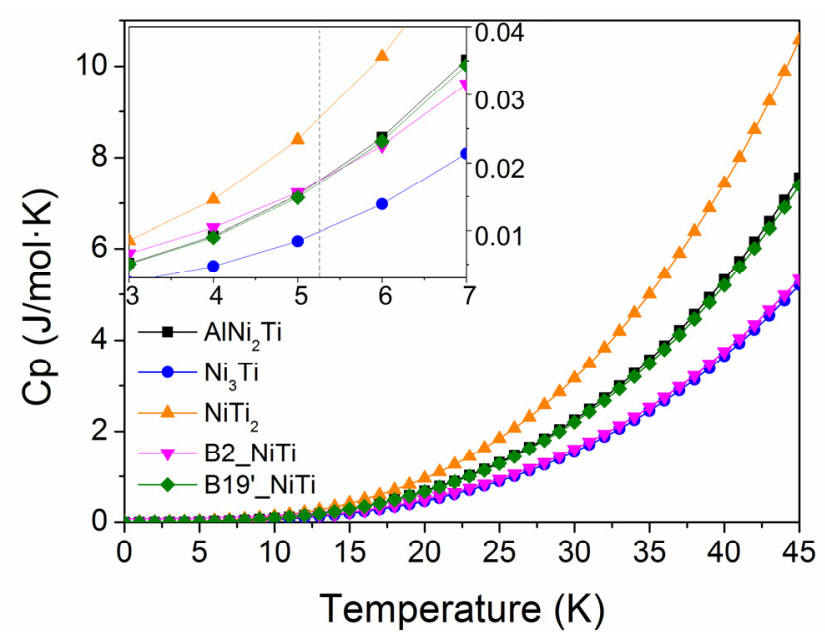

Figure 9. The heat capacity of $\mathrm{AlNi}_{2} \mathrm{Ti}$ and Ni-Ti binary compounds plotted in the range of $0-45 \mathrm{~K}$.

From the illustration at the top left corner of Figure 9, it can be seen that at temperatures up to around $5.25 \mathrm{~K}$, the values of $C_{p}$ have the following order: $\mathrm{NiTi}_{2}>\mathrm{B} 2 \_\mathrm{NiTi}>\mathrm{AlNi}_{2} \mathrm{Ti} \approx \mathrm{B} 19^{\prime}{ }_{-} \mathrm{NiTi}$ $>\mathrm{Ni}_{3} \mathrm{Ti}$, which is the same as the sequence of $\gamma$, indicating that the main contribution to $C_{p}$ is the excitation of electrons at first. The smallest value of $\gamma$ is from $\mathrm{Ni}_{3} \mathrm{Ti}\left(\gamma=0.267 \mathrm{~mJ} /\left(\mathrm{K}^{2} \cdot \mathrm{mol}\right)\right)$, because it has the smallest DOS value at the Fermi level and thus the weakest metallic nature among these compounds. At the temperature from 5.25 to $45 \mathrm{~K}$, and contributions from phonon excitations $(\beta)$ have 
to be taken into account, so the various growth rates result in a different order of $C_{p}$ : $\mathrm{NiTi}_{2}>\mathrm{AlNi}_{2} \mathrm{Ti}$ $\approx \mathrm{B} 19^{\prime} \_\mathrm{NiTi}>\mathrm{B}_{2} \_\mathrm{NiTi} \approx \mathrm{Ni}_{3} \mathrm{Ti}$, the same sequence as $\beta$. The calculated results of $C_{p}$ in Table 5 give the examples below and above $5.25 \mathrm{~K}$, which can demonstrate the distinction clearly. Therefore, it is concluded that the $C_{p}$ curve is dominated by the heat capacity from electrons at first and when the temperature further rises the heat capacity is mainly determined by phonon excitation.

\subsection{Formatting of Mathematical Components}

The electronic properties of $\mathrm{AlNi}_{2} \mathrm{Ti}$ are investigated by calculating the total density of states (TDOS) and partial density of states (PDOS). As shown in Figure 10, there are two sharp peaks which arise from the Ti-3s and $3 p$ states respectively in the lower energy part of the DOS curve. They are localized and have little effect on chemical bonding. Around the Fermi level, the DOS is mainly composed of three wide peaks. The resonance peak I appearing in the DOS is caused by the hybridization of Al-p and Ni-d orbitals. There exists a hollow between peaks II and III, which reflects the splitting of bonding and anti-bonding states. The bonding states (peak II) mainly consists of Al-p and Ni-d states, while the anti-bonding states above the Fermi level are a conduction band composed of $3 d$ bands of Ti, which form peak III. Obviously, the metallic nature of $\mathrm{AlNi}_{2} \mathrm{Ti}$ can be determined by a nonzero DOS value at the Fermi level (3.81 electrons/eV·f.u.), which provides this compound with an excellent ductile character.

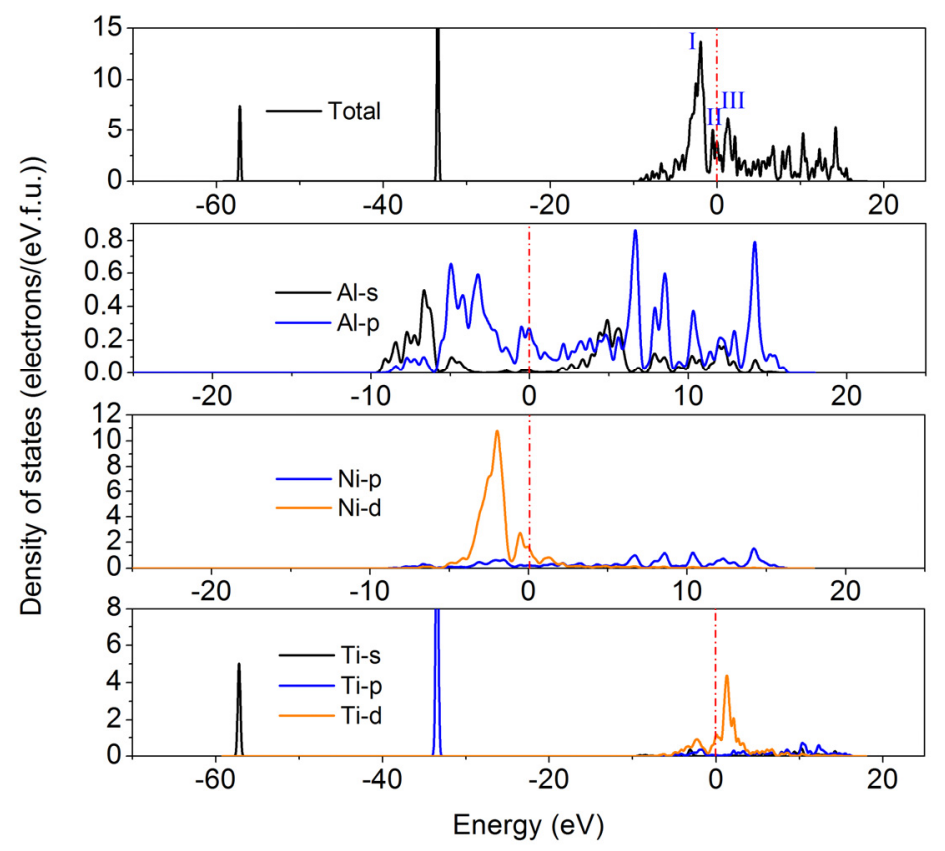

Figure 10. Total and partial density of states of $\mathrm{AlNi}_{2} \mathrm{Ti}$ compound. The Fermi level is indicated by a red vertical line.

\section{Conclusions}

The mechanical and thermodynamic properties of $\mathrm{AlNi}_{2} \mathrm{Ti}$ were investigated by first-principles calculations based on DFT. The mechanical moduli of $\mathrm{AlNi}_{2} \mathrm{Ti}$ were computed from the independent elastic constants. The computed values of bulk, shear and Young's modulus were 164.2, 63.2 and 168.1 GPa, respectively, indicating that it has relatively high mechanical properties. The hardness of $\mathrm{AlNi}_{2} \mathrm{Ti}(4.4 \mathrm{GPa})$ is comparable to common ferrous materials, like martensite steel and white cast iron. Compared with Ni-Ti binary compounds, the hardness and moduli of $\mathrm{AlNi}_{2} \mathrm{Ti}$ are much higher than NiTi and $\mathrm{NiTi}_{2}$, but lower than $\mathrm{Ni}_{3} \mathrm{Ti}$. The intrinsic ductile nature and strong metallic bonding character of $\mathrm{AlNi}_{2} \mathrm{Ti}$ are confirmed by $B / G$ and Poisson's ratio. Besides, $\mathrm{AlNi}_{2} \mathrm{Ti}$ shows the 
isotropy bulk modulus and anisotropic elasticity in different crystallographic directions. Therefore, the existence of $\mathrm{AlNi}_{2} \mathrm{Ti}$ at the $\mathrm{ZTA} / \mathrm{Fe}$ interface will probably benefit the mechanical properties of the composite. At room temperature, the linear thermal expansion coefficient (LTEC) of $\mathrm{AlNi}_{2} \mathrm{Ti}_{\text {, estimated }}$ by quasi-harmonic approximation based on the Debye model, was $10.6 \times 10^{-6} \mathrm{~K}^{-1}$, quite close to LTECs of ZTA and iron, so the thermal shock resistance of the ZTA/Fe composite with an $\mathrm{AlNi}_{2} \mathrm{Ti}$ interfacial phase can be improved. Other thermodynamic properties including Debye temperature, sound velocity, thermal conductivity and heat capacity were also calculated and compared with Ni-Ti binary compounds. The electronic properties of $\mathrm{AlNi}_{2} \mathrm{Ti}$ imply its excellent ductile character.

Acknowledgments: This work was supported by the National Natural Science Foundation of China (51501139); the Science and Technology Project of Guangdong Province in China (2015B010122003, 2015B090926009); and the Science and Technology Project of Guangzhou City in China (201604046009).

Author Contributions: Yefei Li conceived the total investigation and performed the calculations; Shuli Tang analyzed the data and wrote the paper; Yimin Gao supervised the whole work; Qiaoling Zheng contributed the device; Zhiwei Liu and Xiangyi Ren revised the paper.

Conflicts of Interest: The authors declare no conflict of interest. The founding sponsors had no role in the design of the study; in the collection, analyses, or interpretation of data; in the writing of the manuscript, and in the decision to publish the results.

\section{References}

1. Heusler, F. Ueber magnetische manganlegierungen (on magnetic manganese alloys). Verhandlungen der Deutschen Physikalischen Gesellschaft 1903, 5, 219. (In German)

2. Nakata, J.; Terada, Y.; Takizawa, S.; Ohkubo, K.; Mohri, T.; Suzuki, T. Thermal conductivity in $X_{2} Y Z$ heusler type intermetallic compounds. Mater. Trans. JIM 1996, 37, 442-447. [CrossRef]

3. Oxley, D.P.; Tebble, R.S.; Williams, K.C. Heusler alloys. J. Appl. Phys. 1963, 34, 1362-1363. [CrossRef]

4. Bradley, A.J.; Rogers, J.W. The crystal structure of the Heusler alloys. Proc. R. Soc. 1934, A144, 340-359. [CrossRef]

5. Wilson, A.W.; Howe, J.M. Effect of alloying additions on beta' precipitation in NiAl-Ti base alloys. Acta Mater. 2001, 49, 2653-2660. [CrossRef]

6. Koizumi, Y.; Ro, Y.; Nakazawa, S.; Harada, H. NiTi-base intermetallic alloys strengthened by Al substitution. Mater. Sci. Eng. A 1997, 223, 36-41. [CrossRef]

7. Lin, W.; Freeman, A.J. Cohesive properties and electronic-structure of Heusler L2 ${ }_{1}$-phase compounds $\mathrm{Ni}_{2} \mathrm{XAl}$ ( $\mathrm{X}=\mathrm{Ti}, \mathrm{V}, \mathrm{Zr}, \mathrm{Nb}, \mathrm{Hf}$ and Ta). Phys. Rev. B 1992, 45, 61-68. [CrossRef]

8. Ramos, A.S.; Vieira, M.T.; Simoes, S.; Viana, F.; Vieira, M.F. Reaction-assisted diffusion bonding of advanced materials. Defect. Diffus. Forum 2010, 297-301, 972-977. [CrossRef]

9. Bozzolo, G.; Khalil, J.; Bartow, M.R.; Noebe, D. Atomistic modeling of ternary and quaternary ordered intermetallic alloys. In Materials Research Society Symposium Proceedings Vol. 646, Proceedings of the High-Temperature Ordered Intermetallic Alloys IX. Symposium, Boston, MA, USA, 27-29 November 2000; Schneibel, J.H., Hemker, K.J., Noebe, R.D., Hanada, S., Sauthoff, G., Eds.; Materials Research Society: Warrendale, PA, USA, 2001; p. N6.2.1-8.

10. Bozzolo, G.; Noebe, R.B.; Ferrante, J. BFS simulation and experimental analysis of the effect of Ti additions on the structure of NiAl. J. Comput. Aided Mater. Des. 1999, 6, 33-68. [CrossRef]

11. Bozzolo, G.; Noebe, R.B.; Ferrante, J.; Garg, A. Atomistic simulations of alloying additions to NiAl. Mater. Sci. Eng. A 1997, 239-240, 769-776. [CrossRef]

12. Gale, W.F.; Abdo, Z.A.M. Microstructural development in cast alloys based on the $\beta-\mathrm{NiAl}-\beta^{\prime}-\mathrm{Ni}_{2} \mathrm{AlTi}-\gamma^{\prime}-\mathrm{Ni}_{3} \mathrm{Al}-\alpha-\mathrm{Cr}$ system. J. Mater. Sci. 1998, 33, 2299-2304. [CrossRef]

13. Field, R.D.; Darolia, R.; Lahrman, D.F. Precipitation in NiAl/Ni ${ }_{2} \mathrm{AlTi}$ alloys. Scr. Metall. 1989, 23, $1469-1474$. [CrossRef]

14. Cahn, R.W. Nickel Alumina-Titanium Alloy Contg. Epitaxially Related Phases-Having Combined Strength, High Temp. Creep Resistance and Room Temp. Ductility or Plastic Deformability, for Gas Turbine Components. Patent WO9209712-A1, 11 June 1992. 
15. Matano, T.; Kimura, Y.; Miura, S.; Mishima, Y. Microstructure and mechanical properties of the $\mathrm{L1}_{2} / \mathrm{L}_{2}$ two-phase alloys in the quaternary Co-Al-Ni-Ti system. In High-Temperature Ordered Intermetallic Alloys VI. Symposium, Vol. 2, Proceedings of the High-Temperature Ordered Intermetallic Alloys VI. Symposium, Boston, MA, USA, 28 November-1 December 1994; Horton, J., Baker, I., Hanada, S., Noebe, R.D., Schwartz, D.S., Eds.; Materials Research Society: Pittsburgh, PA, USA, 1995; pp. 1377-1382.

16. Mishima, Y.; Lee, E.H.; Liu, C.T. Microstructure, phase constitution and tensile properties of Co-Ni-Ti-Al base multiphase intermetallic alloys. Mater. Trans. 1995, 36, 1031-1040. [CrossRef]

17. Song, G.; Sun, Z.Q.; Poplawsky, J.D.; Xu, X.D.; Chen, M.W.; Liaw, P.K. Primary and secondary precipitates in a hierarchical-precipitate-strengthened ferritic alloy. J. Alloys Compd. 2017, 706, 584-588. [CrossRef]

18. Song, G.; Sun, Z.Q.; Li, L.; Clausen, B.; Zhang, S.Y.; Gao, Y.F.; Liaw, P.K. High temperature deformation mechanism in hierarchical and single precipitate strengthened ferritic alloys by in situ neutron diffraction studies. Sci. Rep. 2017, 7. [CrossRef] [PubMed]

19. Song, G.; Sun, Z.Q.; Clausen, B.; Liaw, P.K. Microstructural characteristics of a $\mathrm{Ni}_{2}$ TiAl-precipitate-strengthened ferritic alloy. J. Alloys Compd. 2017, 693, 921-928. [CrossRef]

20. Song, G.L.; Sun, Z.Q.; Poplawsky, J.D.; Gao, Y.F.; Liaw, P.K. Microstructural evolution of single $\mathrm{Ni}_{2} \mathrm{TiAl}$ or hierarchical $\mathrm{NiAl} / \mathrm{Ni}_{2} \mathrm{TiAl}$ precipitates in Fe-Ni-Al-Cr-Ti ferritic alloys during thermal treatment for elevated-temperature applications. Acta Mater. 2017, 127, 1-16. [CrossRef]

21. Song, G.; Sun, Z.Q.; Li, L.; Xu, X.D.; Rawlings, M.; Liebscher, C.H.; Clausen, B.; Poplawsky, J.; Leonard, D.N.; Huang, S.Y. Ferritic alloys with extreme creep resistance via coherent hierarchical precipitates. Sci. Rep. 2015, 5. [CrossRef] [PubMed]

22. Qian, F.; Sharp, J.; Rainforth, W.M. Microstructural evolution of Mn-based maraging steels and their influences on mechanical properties. Mater. Sci. Eng. A 2016, 674, 286-298. [CrossRef]

23. Qian, F.; Sharp, J.; Rainforth, W.M. Characterisation of $\mathrm{L} 2{ }_{1}$-ordered $\mathrm{Ni}_{2}$ TiAl precipitates in Fe-Mn maraging steel. Mater. Charact. 2016, 118, 199-205. [CrossRef]

24. Liebscher, C.H.; Radmilovic, V.R.; Dahmen, U.; Vo, N.Q.; Dunand, D.C.; Asta, M.; Ghosh, G. A hierarchical microstructure due to chemical ordering in the bcc lattice: Early stages of formation in a ferritic Fe-Al-Cr-Ni-Ti alloy. Acta Mater. 2015, 92, 220-232. [CrossRef]

25. Sun, Z.; Liebscher, C.H.; Huang, S.; Teng, Z.; Song, G.; Wang, G.; Asta, M.; Rawlings, M.; Fine, M.E.; Liaw, P.K. New design aspects of creep-resistant NiAl-strengthened ferritic alloys. Scr. Mater. 2013, 68, 384-388. [CrossRef]

26. Raqlings, M.J.S.; Liebscher, C.H.; Asta, M.; Dunand, D.C. Effect of titanium additions upon microstructure and properties of precipitation-strengthened Fe-Ni-Al-Cr ferritic alloys. Acta Mater. 2017, 128, $103-112$. [CrossRef]

27. Jung, J.; Ghosh, G.; Isheim, D.G.; Olson, B. Design of nanodispersion strengthened TiNi-base shape memory alloys. In Proceedings of the International Conference on Shape Memory and Superelastic Technologies, Pacific Grove, CA, USA, 5-8 May 2003; Pelton, A.R., Duerig, T., Eds.; SMST Society Inc.: Menlo Park, CA, USA, 2004; pp. 23-32.

28. Hsu, D.H.D.; Hornbuckle, B.C.; Valderrama, B.; Barrie, F.; Henderson, H.B.; Thompson, G.B.; Manuel, M.V. The effect of aluminum additions on the thermal, microstructural, and mechanical behavior of NiTiHf shape memory alloys. J. Alloys Compd. 2015, 638, 67-76. [CrossRef]

29. Shi, J.; Gao, Z.H.; Hu, K.; Pan, G.J.; Wei, M.Z.; Xu, L.J.; Meng, X.K. High pseudoelasticity of nanoscale L2 1 phase-Ni43Ti38Al19 thin films. Mater. Lett. 2014, 115, 79-81. [CrossRef]

30. Peters, M.A.; Botton, G.A.; Humphreys, C.J. The precipitation of $\beta^{\prime} \mathrm{Ni}_{2} \mathrm{TiAl}$ from Al-doped $\beta$ Ni-Ti alloys. In Institute of Physics Conference Series Vol. 147: Electron Microscopy and Analysis 1995, Proceedings of the Institute of Physics Electron Microscopy and Analysis Group Conference, Birmingham, England, 12-15 September 1995; Cherns, D., Ed.; IOP Publishing Ltd.: Bristol, UK, 1995; pp. 451-454.

31. Jung, J.; Ghosh, G.; Isheim, D.; Olson, G.B. Precipitation of heusler phase ( $\left.\mathrm{Ni}_{2} \mathrm{TiAl}\right)$ from $\mathrm{B}_{2}-\mathrm{TiNi}$ in Ni-Ti-Al and Ni-Ti-Al-X (X = Hf, Zr) alloys. Metall. Mater. Trans. A 2003, 34, 1221-1235. [CrossRef]

32. Jung, J.; Ghosh, G.; Olson, G.B. A comparative study of precipitation behavior of Heusler phase (Ni $\left.\mathrm{Ni}_{2} \mathrm{Ti}\right)$ from B2-TiNi in Ni-Ti-Al and Ni-Ti-Al-X (X = Hf, Pd, Pt, Zr) alloys. Acta Mater. 2003, 51, 6341-6357. [CrossRef]

33. Tang, S.L.; Gao, Y.M.; Li, Y.F.; Zheng, Q.L. Preparation and interface investigation of iron matrix composite reinforced by alumina particles sintered with Ti and Ni. Adv. Eng. Mater. 2016, 18, 1913-1920. [CrossRef] 
34. Tang, S.L.; Gao, Y.M.; Li, Y.F. Investigation on wear behavior of coated ZTA particles reinforced iron matrix composite. In Proceedings of the 3rd China International Congress on Composite Materials, Hangzhou, China, 21-23 October 2017. (In Chinese)

35. Wen, Z.Q.; Zhao, Y.H.; Hou, H.; Wang, B.; Han, P.D. The mechanical and thermodynamic properties of Heusler compunds $\mathrm{Ni}_{2} \mathrm{XAl}(\mathrm{X}=\mathrm{Sc}, \mathrm{Ti}, \mathrm{V})$ under pressure and temperature: A first-principles study. Mater. Des. 2017, 114, 398-403. [CrossRef]

36. Reddy, P.V.S.; Kanchana, V. Ab initio study of Fermi surface and dynamical properties of $\mathrm{Ni}_{2} \mathrm{XAl}(\mathrm{X}=\mathrm{Ti}, \mathrm{V}$, $\mathrm{Zr}, \mathrm{Nb}$, Hf and Ta). J. Alloys Compd. 2014, 616, 527-534. [CrossRef]

37. Waki, S.; Yamaguchi, Y.; Mitsugi, K. Superconductivity of $\mathrm{Ni}_{2} \mathrm{NbX}(\mathrm{X}=\mathrm{Al}$, Ga and Sn). J. Phys. Soc. Jpn. 1985, 54, 1673-1676. [CrossRef]

38. Durajski, A.P. Quantitative analysis of nonadiabatic effects in dense $\mathrm{H}_{3} \mathrm{~S}$ and $\mathrm{PH}_{3}$ superconductors. Sci. Rep. 2016, 6. [CrossRef] [PubMed]

39. Szczȩśniak, D.; Zemła, T.P. On the high-pressure superconducting phase in platinum hydride. Supercond. Sci. Technol. 2015, 28, 085018. [CrossRef]

40. Sahariya, J.; Ahuja, B.L. Electronic structure of $\mathrm{Ni}_{2} \mathrm{TiAl}$ : Theoretical aspects and Compton scattering measurement. Physica B 2012, 407, 4182-4185. [CrossRef]

41. Zhou, Y.; Chen, Y.; Feng, Y.; Yuan, H.K.; Chen, H. First-principles study on the effect of defects on the electronic and magnetic properties of the $\mathrm{Ti}_{2} \mathrm{NiAl}$ inverse Heusler alloy. Eur. Phys. J. B 2014, 87, 290. [CrossRef]

42. Segall, M.D.; Lindan, P.J.D.; Probert, M.J.; Pickard, C.J.; Hasnip, P.J.; Clark, S.J.; Payne, M.C. First-principles simulations: Ideas, illustrations and the CASTEP code. J. Phys. Condens. Matter 2002, 14, 2717-2744. [CrossRef]

43. Mattsson, A.E.; Schultz, P.A.; Desjarlais, M.P.; Mattsson, T.R.; Leung, K. Designing meaningful density functional theory calculations in materials science-A primer. Modell. Simul. Mater. Sci. Eng. 2005, 13, R1-R31. [CrossRef]

44. Cao, L.Z.; Shen, J.; Chen, N.X. Theoretical study of the phase stability and site preference for $\mathrm{R}_{3}(\mathrm{Fe}, \mathrm{T})_{29}(\mathrm{R}=$ $\mathrm{Nd}, \mathrm{Sm} ; \mathrm{T}=\mathrm{V}, \mathrm{Ti}, \mathrm{Cr}, \mathrm{Cu}, \mathrm{Nb}, \mathrm{Mo}, \mathrm{Ag})$. J. Alloys Compd. 2002, 336, 18-28. [CrossRef]

45. Monkhorst, H.J.; Pack, J.D. Special points for Brillouin-zone integrations. Phys. Rev. B 1976, 13, 5188-5192. [CrossRef]

46. Perdew, J.P.; Burke, K.; Wang, Y. Generalized gradient approximation for the exchange-correlation hole of a many-electron system. Phys. Rev. B 1996, 54, 16533-16539. [CrossRef]

47. Debski, A.; Gasior, W.; Sypien, A.; Goral, A. Enthalpy of formation of intermetallic phases from Al-Ni and Al-Ni-Ti systems. Intermetallics 2013, 42, 92-98. [CrossRef]

48. Huneau, B.; Rogl, P.; Zeng, K.; Schmid-Fetzer, R.; Bohn, M.; Bauer, J. The ternary system Al-Ni-Ti Part I: Isothermal section at $900^{\circ} \mathrm{C}$; Experimental investigation and thermodynamic calculation. Intermetallics 1999, 7, 1337-1345. [CrossRef]

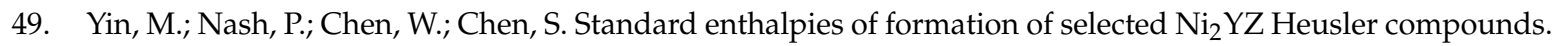
J. Alloys Compd. 2016, 660, 258-265. [CrossRef]

50. Pearson, W.B. Handbook of Lattice Spacings and Structures of Metals; Pergamon: New York, NY, USA, 1967; Volume 2.

51. Jiang, D.T.; Guo, J.T.; Shi, C.X.; Lin, D.L. Microstructure and compressive properties of in situ composite (Ni-40Al-10Ti)-(0, 20\%)TiC. J. Mater. Sci. Lett. 2000, 19, 115-117. [CrossRef]

52. Yan, X.L.; Grytsiv, A.; Rogl, P.; Pomjakushin, V.; Palm, M. The Heusler phase $\mathrm{Ti}_{25}\left(\mathrm{Fe}_{50-x} \mathrm{Ni}_{x}\right) \mathrm{Al}_{25}(0 \leq x \leq$ 50); structure and constitution. J. Phase Equilib. Diffus. 2008, 29, 500-508. [CrossRef]

53. Sridharan, S.; Nowotny, H.; Wayne, S.F. Investigations within the quaternary system titanium—nickel—alumina—carbon. Monatsh. Chem. 1983, 114, 127-135. [CrossRef]

54. Hu, R.X.; Nash, P.; Chen, Q. Enthalpy of formation in the Al-Ni-Ti system. J. Phase Equilib. Diffus. 2009, 30, 559-563. [CrossRef]

55. Li, Y.F.; Tang, S.L.; Gao, Y.M.; Ma, S.Q.; Zheng, Q.L.; Cheng, Y.H. Mechanical and thermodynamic properties of intermetallic compounds in the Ni-Ti system. Int. J. Mod. Phys. B 2017, 31. [CrossRef]

56. Zhao, J.J.; Winey, J.M.; Gupta, Y.M. First-principles calculations of second- and third-order elastic constants for single crystals of arbitrary symmetry. Phys. Rev. B 2007, 75. [CrossRef] 
57. Patil, S.K.R.; Khare, S.V.; Tuttle, B.R.; Bording, J.K.; Kodambaka, S. Mechanical stability of possible structures of PtN investigated using first-principles calculations. Phys. Rev. B 2006, 73. [CrossRef]

58. Born, M.; Huang, K. Dynamical Theory of Crystal Lattices; Oxford University Press: London, UK, 1954.

59. Wu, Z.J.; Zhao, E.J.; Xiang, H.P.; Hao, X.F.; Liu, X.J.; Meng, J. Crystal structures and elastic properties of superhard $\mathrm{IrN}_{2}$ and $\mathrm{IrN}_{3}$ from first principles. Phys. Rev. B 2007, 76. [CrossRef]

60. Zhang, B.; Wu, L.L.; Wan, B.; Zhang, J.W.; Li, Z.H.; Gou, H.Y. Structural evolution, mechanical properties, and electronic structure of Al-Mg-Si compounds from first principles. J. Mater. Sci. 2015, 50, 6498-6509. [CrossRef]

61. Zhou, W.; Liu, L.J.; Li, B.L.; Wu, P.; Song, Q.G. Structural, elastic and electronic properties of intermetallics in the Pt-Sn system: A density functional investigation. Comput. Mater. Sci. 2009, 46, 921-931. [CrossRef]

62. Chung, D.H.; Buessem, W.R. The elastic anisotropy of crystals. J. Appl. Phys. 1967, 38, 2010-2012. [CrossRef]

63. Chung, D.H.; Buessem, W.R. The Voigt-Reuss-Hill approximation and elastic moduli of polycrystalline MgO, $\mathrm{CaF}_{2}, \beta-\mathrm{ZnS}, \mathrm{ZnSe}$, and CdTe. J. Appl. Phys. 1967, 38, 2535-2540. [CrossRef]

64. Chung, D.H.; Buessem, W.R. The Voigt-Reuss-Hill (VRH) approximation and the elastic moduli of polycrystalline $\mathrm{ZnO}, \mathrm{TiO}_{2}$ (rutile), and $\alpha-\mathrm{Al}_{2} \mathrm{O}_{3}$. J. Appl. Phys. 1968, 39, 2777-2782. [CrossRef]

65. Xiang, H.P.; $\mathrm{Wu}, \mathrm{Z}$.J. Ab initio study on the electronic, magnetic, and mechanical properties of $\mathrm{CaCu}_{3} \mathrm{~V}_{4} \mathrm{O}_{12}$. Inorg. Chem. 2008, 47, 2706-2709. [CrossRef] [PubMed]

66. Chen, X.Q.; Niu, H.Y.; Li, D.Z.; Li, Y.Y. Modeling hardness of polycrystalline materials and bulk metallic glasses. Intermetallics 2011, 19, 1275-1281. [CrossRef]

67. Li, Y.F.; Gao, Y.M.; Xiao, B.; Min, T.; Fan, Z.J.; Ma, S.Q.; Xu, L.L. Theoretical study on the stability, elasticity, hardness and electronic structures of W-C binary compounds. J. Alloys Compd. 2010, 502, 28-37. [CrossRef]

68. Teter, D.M. Computional alchemy: The search for new superhard materials. MRS Bull. 1998, $23,22-27$. [CrossRef]

69. Chen, K.; Zhao, L. Elastic properties, thermal expansion coefficients and electronic structures of $\operatorname{Ti}_{0.75} \mathrm{X}_{0.25} \mathrm{C}$ carbides. J. Phys. Chem. Solids 2007, 68, 1805-1811. [CrossRef]

70. Šimůnek, A.; Vackář, J. Hardness of covalent and ionic crystals: First-principle calculations. Phys. Rev. Lett. 2006, 96. [CrossRef] [PubMed]

71. Pabst, W.; Tichá, G.; Gregorová, E. Effective elastic properties of alumina-zirconia composite ceramics part 3. Calculation of elastic moduli of polycrystalline alumina and zirconia from monocrystal data. J. Ceram.-Silikáty 2004, 48, 41-48.

72. Birch, F. Finite elastic strain of cubic crystals. Phys. Rev. 1947, 71, 809-824. [CrossRef]

73. Manghnani, M.H.; Fisher, E.S.; Brower, W.S., Jr. Temperature dependence of the elastic constants of single-crystal rutile. J. Phys. Chem. Solids 1972, 33, 2149-2159. [CrossRef]

74. Otero-de-da-Roza, A.; Luaña, V. GIBBS2: A new version of the quasi-harmonic model code. I. Robust treatment of the static data. Comput. Phys. Commun. 2011, 182, 1708-1720. [CrossRef]

75. Nye, J.F. Physical Properties of Crystals; Oxford University Press: London, UK, 1985.

76. Ravindran, P.; Fast, L.; Korzhavyi, P.A.; Johansson, B.; Wills, J.; Eriksson, O. Density functional theory for calculation of elastic properties of orthorhombic crystals: Application to TiSi 2 . J. Appl. Phys. 1998, 84, 4891-4904. [CrossRef]

77. Xiang, H.M.; Feng, Z.H.; Zhou, Y.C. Theoretical investigations on mechanical anisotropy and intrinsic thermal conductivity of $\mathrm{YbAlO}_{3}$. J. Eur. Ceram. Soc. 2015, 35, 1549-1557. [CrossRef]

78. Ranganathan, S.I.; Ostoja-Starzewski, M. Universal elastic anisotropy index. Phys. Rev. Lett. $2008,101$. [CrossRef] [PubMed]

79. Mersol, S.A.; Lynch, C.T.; Vahldiek, F.W. Anisotropy in Single Crystal Refractory Compounds; Plenum Press: New York, NY, USA, 1968.

80. Brugger, K. Determination of third-order elastic coefficients in crystals. J. Appl. Phys. 1965, 36, 768-773. [CrossRef]

81. Grimvall, G. Thermophysical Properties of Materials; Elsevier: Amsterdam, The Netherlands, 1999.

82. Feng, J.; Xiao, B.; Wan, C.L.; Qu, Z.X.; Huang, Z.C.; Chen, J.C.; Zhou, R.; Pan, W. Electronic structure, mechanical properties and thermal conductivity of $\mathrm{Ln}_{2} \mathrm{Zr}_{2} \mathrm{O}_{7}(\mathrm{Ln}=\mathrm{La}, \mathrm{Pr}, \mathrm{Nd}, \mathrm{Sm}, \mathrm{Eu}$ and Gd). Acta. Mater. 2011, 59, 1742-1760. [CrossRef]

83. Chong, X.Y.; Jiang, Y.H.; Zhou, R.; Zhu, H.; Feng, J. Electronic structure, anisotropic elastic and thermal properties of the $\eta$ phase $\mathrm{Fe}_{6} \mathrm{~W}_{6}$ C. Comput. Mater. Sci. 2015, 108, 205-211. [CrossRef] 
84. Ding, Y.C.; Xiao, B. Anisotropic elasticity, sound velocity and thermal conductivity of $\mathrm{TiO}_{2}$ polymorphs from first principles calculations. Comput. Mater. Sci. 2014, 82, 202-218. [CrossRef]

85. Anderson, O.L. A simplified method for calculating the Debye temperature from elastic constants. J. Phys. Chem. Solids 1963, 24, 909-917. [CrossRef]

86. Kittel, C. Introduction to Solid State Physics, 8th ed.; John Wiley \& Sons, Inc.: Hoboken, NJ, USA, 2004.

87. Rocha, F.S.D.; Fraga, G.L.F.; Brandao, D.E.; Silva, C.M.D.; Gomes, A.A. Specific heat and electronic structure of Heusler compounds $\mathrm{Ni}_{2} \mathrm{TAl}$ (T = Ti, Zr, Hf, V, Hb, Ta). Physica B 1999, 269, 154-162. [CrossRef]

88. Clarke, D.R. Materials selection guidelines for low thermal conductivity thermal barrier coatings. Surf. Coat. Technol. 2003, 163, 67-74. [CrossRef]

89. Cahill, D.G.; Watson, S.K.; Pohl, R.O. Lower limit to the thermal conductivity of disordered crystals. Phys. Rev. B 1992, 46, 6131-6140. [CrossRef]

90. Zheng, K.H.; Gao, Y.M.; Li, Y.F.; Zhao, S.M.; Wang, J. Three-body abrasive wear resistance of iron matrix composites reinforced with ceramic particles. Proc. Inst. Mech. Eng. Part J J. Eng. Tribol. 2014, 228, 3-10. [CrossRef]

91. ASM International Handbook Committee. ASM Handbook, Vol. 1: Properties and Selection: Irons, Steels and High-Performance Alloys; ASM International: Geauga County, OH, USA, 1993.

92. Onderka, B.; Sypien, A.; Wierzbicka-Miernik, A.; Czeppe, T.; Zabdyr, L.A. Specific heat capacities of some ternary aluminides. J. Phase Equilib. Diffus. 2011, 32, 39-41. [CrossRef]

93. Drulis, M.K.; Czopnik, A.; Drulis, H.; Spanier, J.E.; Ganguly, A.; Barsoum, M.W. On the heat capacity of $\mathrm{Ti}_{3} \mathrm{GeC}_{2}$. Mater. Sci. Eng. B 2005, 119, 159-163. [CrossRef]

(C) 2018 by the authors. Licensee MDPI, Basel, Switzerland. This article is an open access article distributed under the terms and conditions of the Creative Commons Attribution (CC BY) license (http:// creativecommons.org/licenses/by/4.0/). 